Article

\title{
Insights from the Historical Lived Experience of a Fragmented Economy of Welfare in Britain: Poverty, Precarity and the Peck Family 1928-1950
}

\author{
Rosalind Edwards ${ }^{1, *}$ and Val Gillies ${ }^{2}$ \\ 1 Sociology, Social Policy \& Criminology, University of Southampton, Southampton SO17 1BJ, UK \\ 2 Social Sciences, University of Westminster, London W1T 3UW, UK; v.gillies@westminster.ac.uk \\ * Correspondence: r.s.edwards@soton.ac.uk
}

Received: 24 November 2019; Accepted: 12 February 2020; Published: 19 February 2020

\begin{abstract}
We draw upon a 'small history' of one family to throw light on lived experience of welfare in the past, and consider how it may provide some glimpses into what Britain's current economy of welfare trajectory could mean, where the state welfare safety net has holes and an ad hoc charitable safety net is being constructed beneath them. Using archived case notes from the Charity Organisation Society across the interwar period to the comprehensive welfare state, we discuss one family's negotiation of poverty and the fragmented economy of welfare involving nascent state provision and a safety net of myriad charitable bodies, and the need to be judged as respectable and worthy. While lived experience of inequalities of assessment criteria, provision and distribution provide some indication for the potential trajectory of contemporary welfare in Britain, towards fragmented localised settlements, the small history also reveals a muted story of alternatives and reliability.
\end{abstract}

Keywords: poverty; Charity Organisation Society; small history; economy of welfare; lived experience; welfare safety net

\section{Introduction}

Historical case studies of social policy can hold important insights for the present and what yet may come (Green 2016; Newstadt and May 1986). Researching the past is a key source of understanding the playing out of social policy processes in the context of variable economies of welfare, and reasoning from history can generate insights that are otherwise out of reach. In this article, we draw upon a 'small history' of one family to consider how lived experience of welfare in Britain in the past may provide us with some indications of what the current economy of welfare trajectory might mean where the British state welfare safety net has so many holes that an ad hoc charitable safety net is being constructed beneath them.

As many commentators have identified, driven by an austerity agenda, recent British social policy has enacted a fundamental resettlement of welfare (e.g., Ermiston 2017; Farnsworth and Irving 2015; Taylor-Gooby et al. 2017; Watts and Fitzpatrick 2018). The imposition of stringent conditionality and punitive sanction measures, and risk assessment and selective targeting, has cut into the comprehensive post-war welfare state and social citizenship entitlements. ${ }^{1}$ In its place has come a set of emphases on personal responsibility rather than guaranteed rights, and localised welfare settlements and arms-length delivery, with variable patchworks of commissioned and sub-contracted local authority, third sector and private sector responsibilities and provision. Accompanying this, indeed integral to the picture,

1 Albeit entitlement has been gendered and raced (Noble 2009). 
has been the fragmentation of poverty into different types (such as food poverty, period poverty, clothing poverty), and the emergence of ad hoc voluntary initiatives seeking to plug failures of and gaps in welfare provision for specific poverty types, and to support people in crisis (Crossley et al. 2019; Lambie-Mumford 2019; Middlemass et al. 2018). In other words, a localised charitable sector is replacing the universal state as a safety net, but in a far from comprehensive fashion. This is uneven social protection that is defined by precarity and exclusion.

Commentators such as those cited above often review this welfare reform, retrenchment and diversification from the 1970s and its ramping up since 2010, to highlight the neo-liberal policy shifts cutting back from the immediate post-war era of comprehensive welfare citizenship. There also are some insights to be had from looking further back however, to the landscape of provision and experiences of this pre-World War II period with its 'complementary' mixed economy of welfare, including a multitude of particularistic and localised charitable and mutual-aid bodies (Harris 2004). Clearly, there are differences across time and space at the broader social and economic level that militate against direct equations at the administrative level, for example, voluntary agencies now often receive funding for their services by contracting to government rather than from the charitable donations of the great and the good, and corporate responsibility agendas and social entrepreneurship models may now also drive and deliver community provisions. Nonetheless, lived experience of poverty, precarity and negotiating the charitable landscape from the past may share some similarities with the present, and at least indicate some considerations for the future.

The concept of 'lived experience' and its use in social policy making and analysis has recently received attention. McIntosh and Wright (2019) interrogate the ontological, conceptual and methodological possibilities of the notion. McIntosh and Wright argue that "lived experiences are especially relevant where they are shaped and mediated by policies, policy-related discourses and the practices of front-line welfare agencies" (p. 452). They propose the 'shared typical' as a 'structure of feelings' that reveal the wider social structures and narratives that shape and cause disadvantage, disempowerment and oppression. Such an approach can point up the commonality of fear, embarrassment and stigma that is the 'shared typical' of punitive welfare conditionality and receipt of charitable help. McIntosh and Wright also put forward methodologies such as qualitative longitudinal research or longitudinal auto-ethnography, as eminently suited to exploring lived experience, bringing in the temporal dimension of people affected by and living through policy processes. While they position lived experience at the mediation of intersubjective experience and specific historical and temporal locations, however, they do not indicate the potential of 'small history' temporal analysis as an element of this. Our discussion here adds micro histories to the investigatory methods toolbox of lived experience, in line with Middlemass et al. (2018) who call for a bringing together of social science and humanities approaches to researching lived experience.

The small history that we present here is centred on and reconstructed from a series of episodes recorded in an archived case history file of the Peck family concerning their engagement with aspects of the localised economy of welfare provision from 1928 to 1950. The Peck case was selected for in-depth study because it encompassed a family with (initially at least) dependent children, involved details of engagement with multiple agencies, and covered a time of shifting relations between voluntary and statutory services. In the well-known and traversed grand history of British welfare provision, the complexities of families' singular, humble histories often are hidden away except perhaps as brief examples. There is, though, a tradition of using family cases in histories of aspects of social life, including poverty and drawing on archived administrative sources to reconstruct their lives (e.g., Jobs and McDevitt 2005; Shave 2009). We are drawing on a strand of microhistory that puts granular specificities at the centre of interest as valuable in and of themselves (Magnússon 2014), using small histories to restore agency to ordinary people, explain the past and relate to our present through "the fundamental and idiosyncratic humanity" of small stories that "are unfolding in myriad ways today as well" (Laite 2020), as well as connect into the future. 
Our presentation of the Peck case interweaves the fortunes of one family living in precarious circumstances with moments of major shifts in developments of the British welfare state and the nature of charitable provision that were occurring at the time. It touches on aspects of living in poverty that are recurrent, resonating with contemporary conditions of deprivation (Thane 2019), and how a state of precarity is a well-worn feature of capitalist societies rather than a new condition of contemporary neo-liberalism (Kasmir 2018; King and Tomkins 2003). In what follows, we consider the playing out of social policy processes in the vagaries of the Peck's lived experience of poverty and negotiation of the localised charitable landscape and front line particularised charitable agencies from which they seek relief, while in our conclusion, we draw out potential indications of the future of Britain's current economy of welfare trajectory. Along the way, our discussion also reveals the small and muted story that, however labyrinthine and unsatisfactory the fragmented economy of welfare in pre-World War II Britain, where myriad local and charitable and mutual-aid bodies largely played a separate role and met needs distinct from nascent welfare state provision, the advent of the post-war comprehensive welfare state and retreat of charities could rupture a material and social support system, leaving a family adrift.

\section{The Charity Organisation Society and the Peck Family}

The Peck family made their first application to the British Charity Organisation Society in 1928. Walter Peck worked as a clerk and was age 45 at the time; his wife Mabel, 43, was a cleaner, and they had four children: Henry, age 18; Albert, age 16; Cyril (nicknamed Chum), age 8; and Muriel, age 6. The family rented two rooms of a house in North London. We follow their fluctuating fortunes over a period of 22 years, from 1928 to 1950, drawing on archived case notes held in the London Metropolitan Archives detailing their contact with the Charity Organisation Society or COS. ${ }^{2}$

COS was founded in 1869, with the aim of coordinating the multitude of philanthropic activities of the time (Humphreys 2001; Lewis 1995; Rooff 1972). Generally, the charitable sector was ensconced in British welfare provision as 'buffer institutions' that mediated the relationship between citizens and the state, a first resort for the deserving poor as part of the economy of welfare, while the state in the form of the Poor Law dealt with irredeemable paupers (Lewis 1995; Thane 1990). By the early twentieth century however, there was a developing welfare state system, and relations between the British state and the charitable sector shifted towards the latter complementing the former in the economy of welfare (Finlayson 1994; Harris 2004). Voluntary sector complementarity was firmly embedded in the comprehensive welfare state in Britain after World War II, with charities seeking to attract local government funding for delivering distinctive services.

The COS approach to charitable relief involved thorough case work investigation of requests for support including through home visiting (a practice that evolved into modern day social work). The methodical approach to interrogating family circumstances resulted in sets of meticulous case files. The Peck family papers are one of many archived COS cases, stretching from the organisation's foundation through to the mid-1960s. ${ }^{3}$ The Peck case is one of the largest of the period amounting to 141 pages, standing out in the length of time of the relationship between the family and the charity, and thus in the amount of interest and help that the Pecks received. It is an important small history file because, as we will see, as well as conveying the lived experience of poverty, precarity and negotiating an ad hoc charitable safety net, it tells what is otherwise a muted story of lived experience of the shift in the British economy of welfare during the period.

2 The organisation still exists today under the name of Family Action. The Charity Organisation Society records are lodged with the London Metropolitan Archive under the collection name of a subsequent guise: Family Welfare Association. The COS papers are London-based, but not all concern families with dependent children or involve multiple agencies. Metadata about the collection and access to it can be found at: https://search.lma.gov.uk/scripts/mwimain.dll/144/LMA_OPAC/web_ detail/REFD+A $\sim\{2$ FFWA?SESSIONSEARCH.

3 London Metropolitan Archive box reference A/FWA/TH/B/02/001 (St Pancras (North) case papers numbered 1-12). 
The material includes mainly handwritten, detailed case notes and correspondence with and from a range of charitable organisations, but there are also letters from members of the Peck family that provide us with their direct (albeit partial) words rather than their reported (equally partial) voices. ${ }^{4}$ Occasionally we augmented the file information with dates about family members' marriages and deaths obtained via www.freebmd.org.uk. We have walked the tricky ethical line of telling an intimate small history of one family whose members have no ability to consent, and where our rationale and rigour lies in presenting and interpreting the detail of their lived experience (Lepore 2001). In line with this, we have named the family. Family Welfare Association (COS) records that are over 60 years old are open for public consultation (see access information provided by the London Metropolitan Archives for the Collection: https://search.lma.gov.uk/scripts/mwimain.dll/144/LMA_OPAC/web_detail/REFD+ A $\sim\{2$ FFWA?SESSIONSEARCH). This applies to the Peck file. Further, Mr. and Mrs. Peck have died (as noted later in this article), and it is likely their children are dead too (the youngest, Muriel, would be 100 years old this year). Pro-actively tracing and seeking consent from any descendants could be considered unethical in its own right. That said, it is just as likely as not that any Peck family descendants might be pleased to come across their family history and the existence of the file. As part of our ethical practice, we have aimed to treat the Peck's story with respect. ${ }^{5}$ The period that the Peck family file covers saw several major historical developments in Britain and more widely. Notably for the small history here, these included the world-wide economic Great Depression or Great Slump following on the Wall Street Crash, between 1930 and 1934 in Britain, with accompanying widespread unemployment; the 1939 to 1945 Second World War imposing conscription and seeing major cities in Britain suffer bombing attacks; and the advent of a comprehensive British welfare state system in a series of legislation from 1945, with consequent shifts in the provision of support to disadvantaged families. ${ }^{6}$ In terms of the charitable safety net of welfare, by the late 1920s, COS's primary role involved their distinct casework practice in the delivery or obtaining of grants for necessities and convalescent aid. The nature of the adversities in the Peck's story illuminates some recurrent struggles for poor families across time. Notably, we can see the way that ill health, unfit housing, and in and out of work poverty, intersect to create a precarious existence for families such as the Pecks, as they: "... are always on the border line between managing and not being able to manage" (Case Officer notes, Charity Organisation Society, 2nd September 1944).

\section{Precarity and Negotiating the Charitable Safety Net in the 1930s}

Mrs. Peck first approached the local district committee of London COS in May 1928 because Mr. Peck had been in hospital with emphysema (chronic obstructionary pulmonary disease). Mrs. Peck's income from cleaning and the contributions from their oldest two working sons were not enough to support the household. At that time, a British National Health Insurance scheme covered low income workers, but with a strict sickness benefits cut-off point designed to discourage malingering. Mr. Peck's benefit had been cut by half. The case file summary for May 1928 notes: “... [COS] interviewer favourably impressed with Mrs. Peck as a 'superior quietly dressed woman'. All references gave good reports of family. Home was clean, neat and cheery." In other words, the case worker judged the family respectable enough to be helped. The district COS Committee obtained a grant of money for the Pecks from the United Services Fund (USF), a charity that helped those who had served in the First World War (as Mr. Peck had done). A month on, Mr. Peck was reinstated as the family's main breadwinner, as a clerk at the National Amalgamated Assurance Company.

4 All accounts, whether caseworker notes or letters from discrete charitable agencies or from clients such as the Pecks as in this case, are relational and partial in the sense of being produced for a purpose, from a particular social location, with selected inclusion and silences, and reflecting personal and institutional relationships and inequalities, as well as being filtered through the lenses of researchers who produce analyses (e.g., Peel 2011; Starkey 2007).

5 The project received ethical approval under University of Southampton ERGO No. 13553.

6 For an overview of levels of poverty and unemployment, and average income and expenditure across these periods see Gazeley (2003). 
Seven months later, the Pecks approached COS again, so that 7-year-old Muriel could have her own bed rather than sharing with her parents. The district COS Committee agreed a grant on condition that, now Mr. Peck was earning again, it was to be repaid in instalments, emphasising ideas about responsibility and self-sufficiency. There was a brief break in the repayments when Mr. Peck was ill once more, but Mrs. Peck continued them when her husband returned to his job. The summary log records:

Jan. 1929 Re-application for bed and bedding. Muriel ... used to sleep with parents but as delicate mother would prefer her to have separate bed. Committee granted bed and bedding. Asked parents to pay 30/-. Paid 3 weeks—-total 7/--then husband ill again. ${ }^{7}$

Later that year, in July, the Pecks applied for and were granted funding to cover a replacement for Mr. Peck's badly fitting false teeth (extensive tooth extraction was quite common at the time (Barnett 2017; Baumgartner et al. 2008)). COS recognised that providing a new set of false teeth could raise self-confidence, and ensure people were more presentable and better able to find work. Additionally that year, Mrs. Peck was given an additional part-time cleaning job in the COS district office. The Peck family's combined income was only sufficient for a while, however. In Spring 1930, the Peck's oldest son got married, and the loss of his financial contribution reduced the household's income. Further, 1931 saw Mr. Peck unwell again between February and October, when he was then pronounced fit for work by the then British Ministry of Labour. Mr. Peck, though, was not regarded as strong enough by his employer:

The Medical Officer for the Society where he works says he is not fit to return to work, and he has therefore been asked to tender his resignation as being incapable of carrying out his job (23 October 1931).

The Ministry would not change their judgement despite COS's appeal to them, however (see Figure 1), replying to the COS case officer:

This man was reviewed on the 12 October by the Regional Medical Officer appointed by the Ministry of Health and found to be capable of work ... it would be impossible for me to alter their decision in any way.

In response, COS agreed interim help and supported another application to the United Services Fund.

Mr. Peck's chronic ill health continued and meant that, after 1933, he was never able to work again. From this point, it becomes clear that, for the Pecks, COS was a central material and social support that they could turn to, to help them negotiate the nascent welfare state and ad hoc charitable safety net that might enable them to attempt to manage their precarious situation. For example, COS aided the Pecks with obtaining financial help from state National Health Insurance and the British Legion charity during several bouts of poor health for Mr. Peck, while in 1937, COS provided the Pecks with money for an extra bed and bedding because the family wanted to move and rent three rather than two rooms:

March 1937 Re-application for extra bed. All children now earning. Albert 25 married-Cyril 17, van boy for John Lyons earning 19/- Muriel 14 $\frac{1}{2}$, earning 15/- Children gave all they earned to Mother. Still getting 10/- N.H.I. Wanted extra bed as needed 3 rooms, overcrowded in 2. Bed and bedding supplied.

Poverty rates rose in Britain in the 1930s (although the cost of living dropped (Gazeley 2003)), and the focus on this issue has been largely on the growth in unemployment created by the Great

7 The amounts here and in other quotes are in the pre-decimal currency of pounds, shillings and pence $(£, \mathrm{~s}, \mathrm{~d})$ used in Britain until 1971, with shillings often represented by $n /-$. 
Depression. Unemployment rates varied for different regions of the country, however, and were relatively low in London (Stevenson and Cook 1979). Families whose members were in employment could also face deprivation, however. By 1937, as well as Mrs. Peck's part-time cleaning jobs, Cyril, age 17, and the 14-year-old Muriel were both working and giving their earnings to the family. Yet, while work-class young people were crucial contributors to family income in the interwar period, they were a source of low paid labour (Todd 2007), which meant that the Pecks could not afford anything beyond the basics. As for 17 per cent of families generally at that time, they had no margin available for saving (Thane 1982) and any misfortunes could push them over the edge into not managing and further poverty.

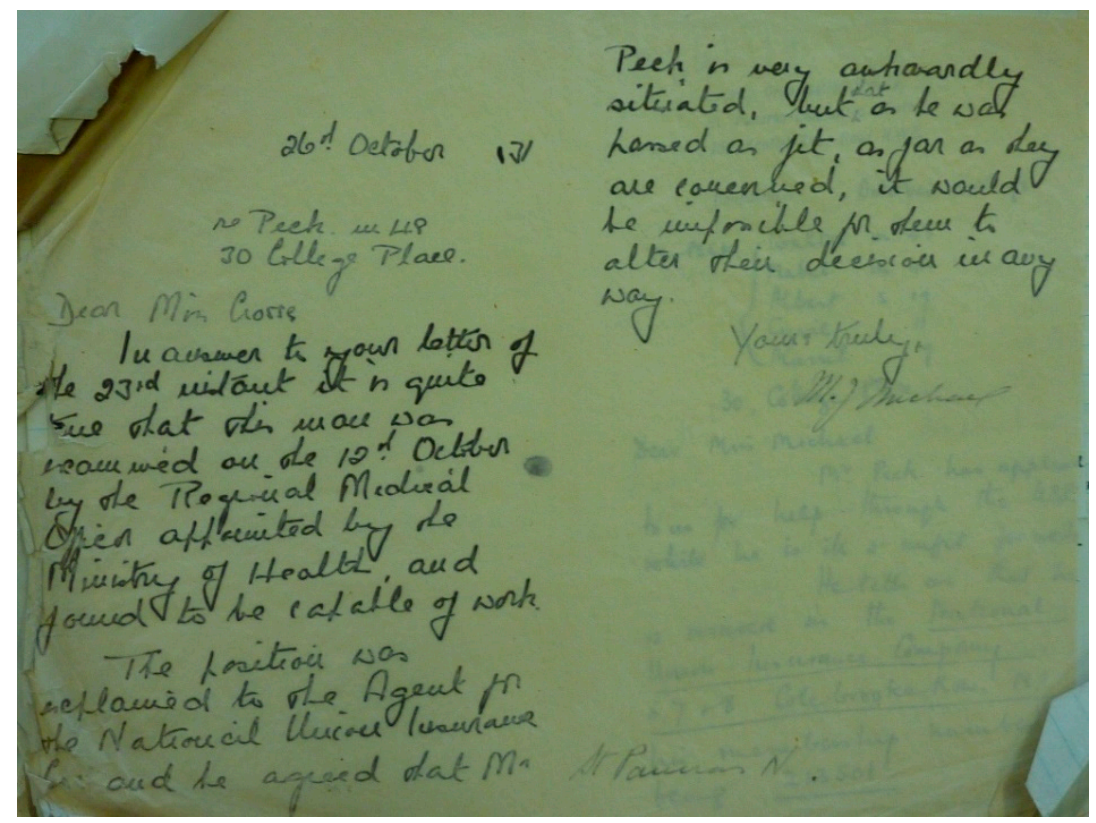

Figure 1. Letter to COS (Charity Organisation Society) confirming Mr. Peck's fitness to work. 26 October 1931.

\section{Wartime Misfortunes and the Welfare Labyrinth}

Cyril was called up to join the army in 1939. The loss of his income was felt by the Pecks, resulting in another application to COS. Although Mrs. Peck was receiving an army allowance from Cyril, she was having to keep up the payments that he was making to a clothing club for himself and his father. With COS advice, Mrs. Peck started going backwards and forwards between a number of state and charitable agencies. The Soldiers', Sailors' and Airmen's Families Association (SSAFA) (an armed services charity) said that they could not help the family because their income was judged to be adequate, while the Unemployment Assistance Board (UAB) (which administered a system of means-tested benefits) told Mrs. Peck that because she was the mother, not the wife, of a serving man, she was not entitled to any help:

September (1939)—Applied again as Cyril called up therefore deprived of his $£ 1$. Mrs. Peck earning 12/- N.H.I. 10/6 Muriel 16/- Allottment [sic] 8/3 Referred to P.A. No Government allowance. SSAFA considered income sufficient.

14.10.39 Called and saw Mrs. Peck, who said they went to R.O. [Government Relieving Officer] who said they ought to apply to U.A.B. so they went to U.A.B. who said they could not help as Mrs. Peck was the mother and not wife of man ... They are to go to R.O. again tomorrow and get final decision-they have had food tickets. Mrs. Peck explained that she only got $5 / 2$ out of $8 / 2$ from her son as she had to pay $8 /-$ p.w. for his clothing club. The boy pays $8 /$ - p.w. for his own clothes and $1 /$ - for his father's. 
The Pecks were at the mercy of the different conditionalities of charities and the state system, falling between them (against the backdrop of wartime restrictions and rationing (Zweiniger-Bargielowska 2002)). Mrs. Peck did, though, receive some food tickets from COS. On a visit a year later, she was provided with: " 3 tins of soup and one of peas and one of pineapple as Muriel's wages will be short this week" (14 November 1940).

By the summer of 1940, the Pecks' accommodation was giving COS cause for concern, and they noted that finding the family other accommodation "would be a good thing as they are overcrowded and living in a very nasty house" (22 July 1940). After one visit to the family home on 26tJuly, the case notes record:

The living room is a large one and furnished with a chest of drawers, side-board, table, some wooden chairs and a double bed. Mr. Peck had to sleep there when all the snow was about as the water dripped through in the other room. Sticking paper was put neatly over one or two cracks in the wall, and there were certainly some patches where damp had been coming through.

The inclusion of a remark about the neatness of the sticking paper in the case notes conveys the COS estimation of the Pecks as respectable and worthy of help. COS obtained a grant to cover the Pecks' removal costs from The Regimental Agency. In their request letter to the Agency, COS cited Mr. Peck's army particulars from 1915 and described the Pecks as "very reliable and hardworking people", and this was a rationale for COS and the Agency aiding the Pecks. The Pecks did not hold entitlements to aid as social citizens, rather they must have their worthiness, need and condition acknowledged.

The family were in dire straits again when Mr. Peck's health worsened, and COS wrote to the Regimental Agency to request a grant for extra nourishment for Mr. Peck (see Figure 2):

As you know Mr. Peck has a bad heart, and a very weak chest, and at the moment he is very unwell as a result of tripping over in the dark and falling into his air raid shelter. It would be a great help to the family to have a grant for extra nourishment as they find it hard to provide the diet which Mr. Peck needs. Muriels [sic] work has been very variable lately and she does not always draw a full weeks wages. She has also been off work. (23 November 1940)

The Regimental Agency agreed to two months support only, however. Eventually the Ministry of Health provided a grant to cover the additional cost to the Pecks of purchasing nourishing food. Poor families simply had no money to pay for fresh meat or fruit and often relied on bread and tinned goods. Moreover, the flat rate rationing system introduced in 1940, alongside limited supplies of some fresh foods, made insufficient allowance for particular needs.

As well as food, clothing was also a recurring problem for the Pecks. Throughout the wartime period, they made applications for clothing, with COS supporting them in approaching, variously, the Regimental Agency, SSAFA, British Legion and United Services Fund. Items requested included a coat for Mrs. Peck, and a suit, boots, jacket and overcoat for Mr. Peck. Muriel was also helped with clothing. In 1942, she applied to join the Women's Royal Naval Service (WRNS), for which she would need her own dressing gown. COS obtained one for her from the Personal Service League (PSL), a charity with a remit to help ameliorate poverty. Muriel also wrote a letter expressing gratitude (see Figure 3): "Many thanks to you and the committee for your kindness in getting a Dressing Gown for me, also for all past things that you have so graciously given me." In 1944, COS obtained another overcoat for Mr. Peck. He was very grateful, writing one of many effusive letters that he sent to COS and other charitable societies over the years, thanking them for the help he received (see Figure 3): “ ... May I please offer to you my gratitude and thanks. I would also wish if you be so kind to extend them to all those Ladies and Gents on the committee" (26 October 1944), as well as often visiting the COS Office to extend thanks in person. The deference and felt lack of entitlement to basic clothing is palpable. 


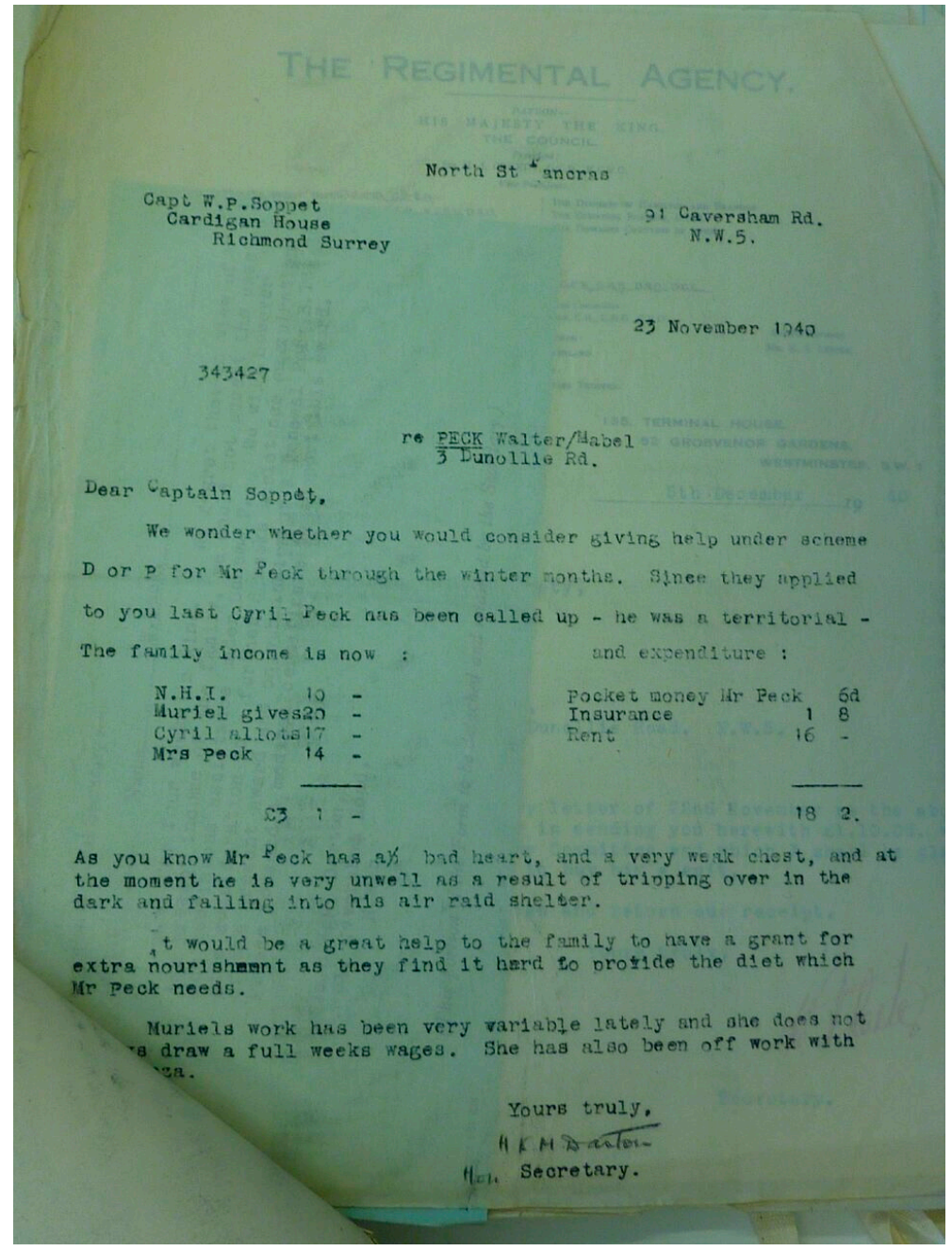

Figure 2. Copy of letter from COS requesting extra nourishment for Mr. Peck, 23 November 1940.

1944 saw Mr. Peck's health deteriorate further, and COS pieced together a multi-charitable package, applying to Invalid Kitchens of London for nourishing dinners to be delivered to him daily, paid for by the British Legion and United Services Fund. Clearly, the couple could not afford to feed themselves sufficiently well. The case notes for that year and into the next are full of COS liaising with a variety of agencies over invalid dinners, vouchers, missing forms and medical certificates, as well as dealing with the question of whether or not Mr. Peck should be making a small contribution towards the cost of his dinners himself:

[Letter to COS from Invalid Kitchens dated 8 November 1944] ... When the BL [British Legion] has finished paying for him if he wishes to continue dinners as I believe he does perhaps he could a little [sic] towards the dinners himself.

[Letter to COS from Invalid Kitchens dated 15 November 1944] ... Mr. Peck wishes to continue dinners and is paying $6 \mathrm{~d}$. towards them.

[Letter to COS from Invalid Kitchens dated 2 March 1945] ... I asked Mr. Peck if he could still manage the $6 \mathrm{~d}$. p.d. that he pays now for his dinners, and he said he gets 10/- N.H.I. gives his wife 10/- and that leaves him 3/- for his dinners. It seemed rather hard to me that he should have no pocket money, but he said he did not drink and smoked very little. You know the family well what do you think should be done? 
[Letter to Invalid Kitchens from COS dated 13 March 1945] ... Whether the British Legion can help Mr. Peck any further depends on the Pecks. If they chose to call and apply for help, we will put it up to Headquarters again.

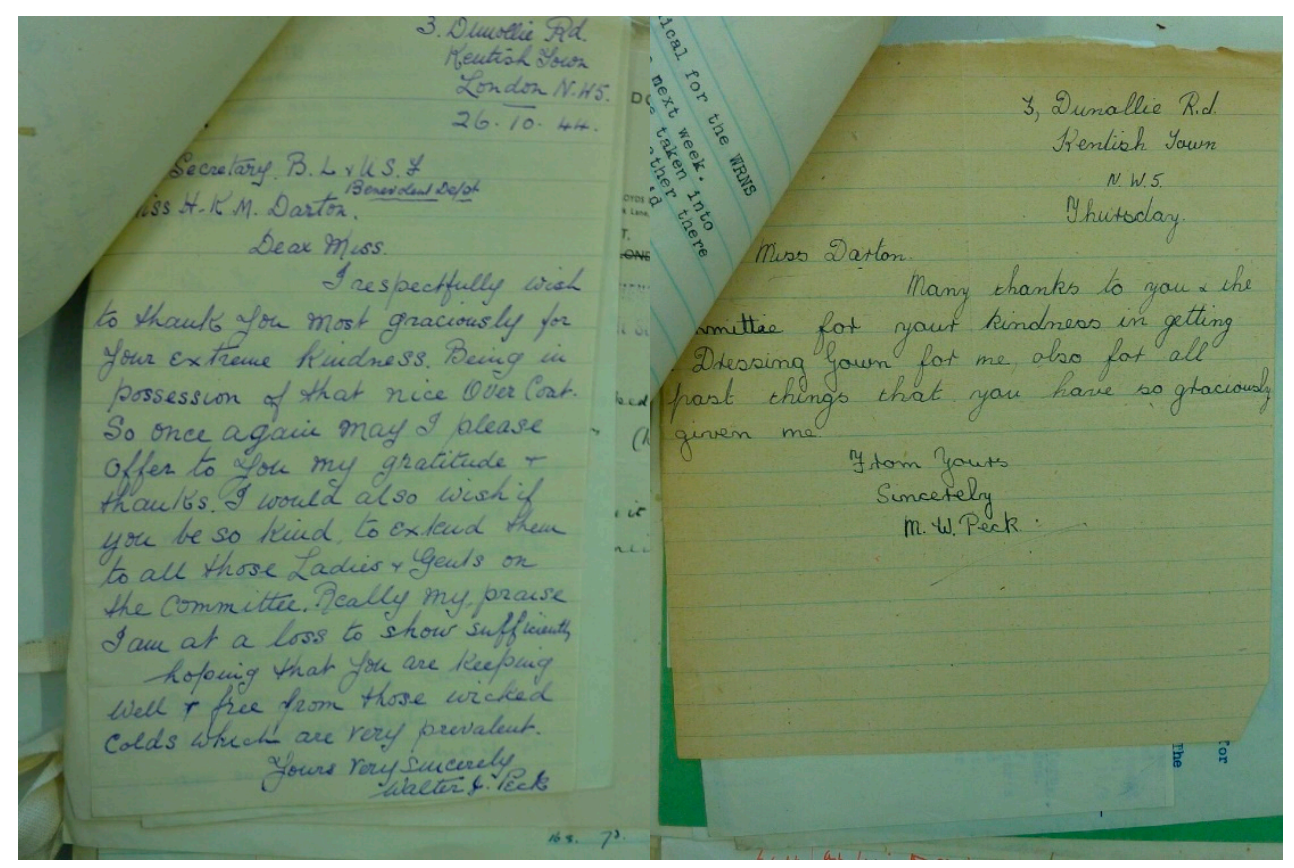

Figure 3. Thank you letters to COS from Mr. Peck, 26 October 1944, and Muriel Peck, undated.

\section{The Advent of the Comprehensive British Welfare State}

In the summer of 1947, after having some remaining teeth extracted at the National Temperance Hospital (prior to its incorporation into Britain's National Health Service in 1948), Mr. Peck was experiencing problems. He applied to COS for support. COS approached a number of agencies about help with the cost of replacement dentures, including a charity supporting those who had experienced combat, The Royal Fusiliers Aid Society, who made a grant. During the COS case worker's investigatory home visit to the Pecks, it also transpired that the Hospital had been charging Mr. Peck for his treatment. To meet the payments, he had borrowed money from his youngest son, Cyril, who was saving to get married. COS took the Hospital to task for their unreasonable assessment of Mr. Peck's ability to pay for treatment, given that the family had "very little money to spare." Chastened, the Hospital offered to refund the payment that Mr. Peck had made so far, and the COS Case Officer recorded (see Figure 4):

17 July 1947 ... Miss Collin said that she had not been dealing with Mr. Peck but she could not bear to think that we considered their assessment unreasonable... She said she would have a talk with the Almoner concerned and probably the 7/6d. would be refunded and the rest of the assessment wiped out. 


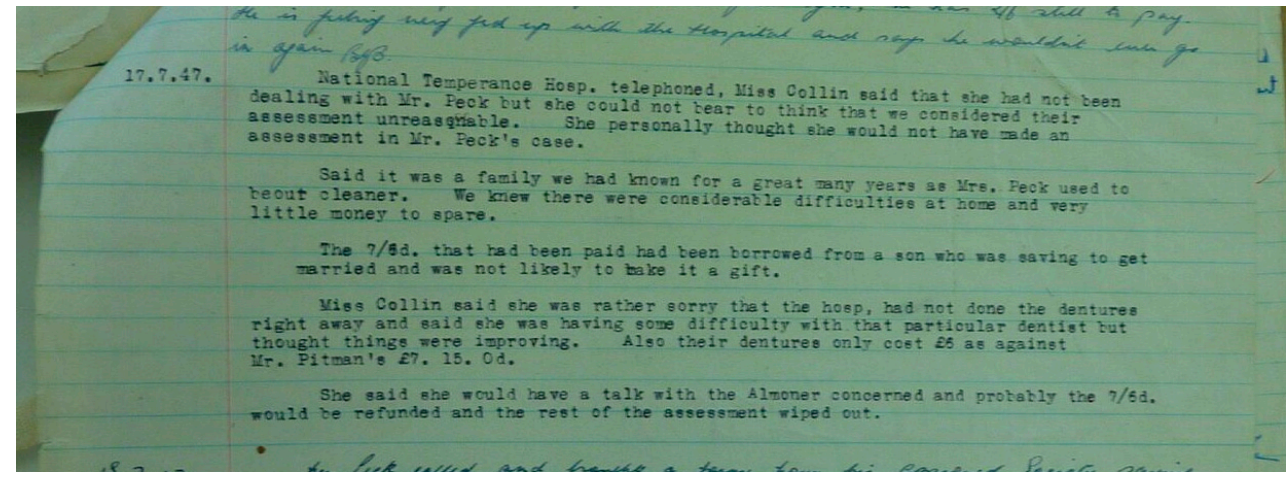

Figure 4. Entry in COS case notes, 17 July 1947.

The whims of local assessment of means, rather than universal entitlement, are evident here. In the event though, Mr. Peck refused the refund because, the case notes record, "he feels very uncomfortable about his poverty" (18 July 1947).

The advent of a post-war comprehensive British welfare state that included a free National Health Service and a social insurance system that covered old age and risks of unemployment and sickness, was to erode these labyrinthine complexities of charges and charitable handouts-though not the shame that could be attached to being poor. Rates of poverty fell, albeit the institution of the welfare state did not eliminate poverty. The largest group in poverty in Britain in the 1950s were the elderly (Cole and Utting 1962). By the end of the second World War, at 64 and 62 respectively, Mr. and Mrs. Peck were approaching or at pensionable age (65 for men and 60 for women). At the same time as Mr. Peck's misfortunes with his teeth, in July 1947, Mrs. Peck is recorded as saying that she had applied to the 'Assistance Board' for the means-tested supplementary pension (Public Assistance Committees became the National Assistance Board in the subsequent year, 1948, set up to cover those not insured). She was told that she was not eligible, however.

The Peck's difficulties with meeting additional costs beyond a very basic household budget continued. Mr. Peck had been to a local optician and was prescribed two new pairs of glasses. COS obtained a grant from the obliging Royal Fusiliers Aid Society to meet the costs. Mr. Peck also wrote a deferential request for a pair of shoes for the winter on 23 September 1947 as his old ones were not watertight and beyond repair.:

Do you think I shall be asking too much of you, without any offence whatsoever, as my shoes are not watertight and beyond repair, assist me in obtaining a new pair. I'm sorry to trouble you, at the same time I shall be most pleased if you can. Once again apologising for being such a worry to you, "Size 5" should you require my size in footwear.

COS drew a dead end with the Women's Voluntary Service (WVS) but the PSL were able to supply a pair, albeit slightly large so that Mr. Peck had to wear thick socks in order that the shoes fitted.

In the meantime, COS had renamed itself the Family Welfare Association or FWA in 1946, and its casework became increasingly focused on therapeutic style efforts to strengthen family relationships, reflecting anxieties about the effects of the war on family stability (Lewis 1995; Rooff 1972). The FWA's focus turned to complementing the British welfare state's social services provision and maintaining a distinction from other charities through providing contracted specialist psychodynamic case work. The Pecks no longer fitted the client and service profile that the FWA were seeking to carve out for themselves. The newly universal British welfare state of social entitlement, with its 'cradle to grave' coverage, reinforced this stance. In 1950, the couple called into the FWA office and Mr. Peck reported that their landlady, Mrs. Hall, was persecuting them and tormenting their cat, which they had had for 11 years, because she did not want it in her garden. He broke down and asked for help with being rehoused: 
12 July 1950 ... The Pecks wanted us to help them get rehoused as they say the situation with Mrs. Hall is now unbearable, but it was explained that we couldn't help with housing problems and they went sadly away.

Having helped the Pecks with housing moves over the course of their 22-year involvement with the family, the FWA's shift in remit meant that this was now outside of their service provision. The nature of the relationship that the Pecks and COS/FWA had built with each other was redundant. The case file ends.

Walter Peck died some months after the Pecks' last contact with the Family Welfare Association, in March 1951, age 67. His wife, Mabel, survived him by four years, and died in September 1955, age 70.

\section{Contemporary Resonances}

The Peck family's archived case notes provide us with a small history insight into and feel for the way that broad and recurrent social problems of in and out of work poverty, ill health, and unfit housing, profoundly affected an individual family in early to mid-twentieth century Britain. The fluctuating fortunes experienced by the Pecks show us the detail of lived experience of issues that have long been associated with a precarious existence and that remain with us to this day, providing a connection of a small history with the present. This is evident in the detail of the everyday material resources that the Pecks approached COS to help them obtain. The provision of food tickets and tinned foods to Mrs. Peck raises the rapid expansion of food banks and their use in 21st century Britain (Garthwaite 2016; Lambie-Mumford 2019). Poor families continue to rely on bread and tinned goods today. The contemporary appearance of localised clothing banks in Britain to address 'clothing poverty' (e.g., Sharewear: https://sharewearclothingscheme.org/) echoes the Pecks' reliance on a charitable safety net for dressing gowns, coats and shoes. Indeed, the Pecks' circumstances in the late 1930s illustrate an enduring social issue that resonates down to today, that of in-work poverty (e.g., Goulden 2019), where with Mrs. Peck, and a son and daughter contributing their earning to the family budget, it was still not enough to live on. Later in their lives, Mr. and Mrs. Peck were part of the elderly in poverty in the 1950s-a situation that is coming to the fore again in the context of the UK's low basic pension and means-tested supplements (Ebbinghaus 2019).

The contemporary resonance of small histories of lived experiences can also be seen in the attitudes towards and judgements about the Pecks, as well as those that they are recorded as displaying in the case records. The emphasis on ideas about responsibility and self-sufficiency, demonstrated in the district COS Committee agreeing a grant for Muriel's bed on condition it was repaid in instalments, echoes the rationale for the British state's current Budgeting Loan system and conditionality. The Ministry of Labour's decision that Mr. Peck was fit for work, despite medical evidence to the contrary, contains echoes of current cases of people being assessed as fit for work, who clearly are not, by what is now the British government's Department for Work and Pensions. ${ }^{8}$ The grounds for the Regimental Agency grant to the Pecks to cover their removal costs was on the basis of them being judged a reliable and hardworking family. 'Hardworking' families are viewed favourably by the British government now as then (Runswick-Cole et al. 2016), with social entitlement established on the basis of worthiness. The shame and stigma felt by those in poverty is also another small history connection with contemporary Britain, with its connotations of irresponsible consumption and failure to 'manage' everyday hardship (Shildrick 2018). The lived experience of "shared typical" and "structure of feelings" that (McIntosh and Wright 2019) identify echoes across time.

8 For example, BBC, 'More than 2300 died after fit for work assessment-DWP figures', (27 August 2015): https://www.bbc.co, uk/news/uk-34074557 [accessed on 28 May 2019]. 


\section{Conclusions}

Precarity is an economic and social condition for those in society with an inadequate income, especially where universal and sufficient social protections are limited. The Pecks can be seen as a family constantly teetering on the edge of managing and not managing, as in the estimation of their COS case officer in the quote earlier in this paper. In truth though, it was not a question of whether the Pecks were able to manage; they were in a situation that plainly was not 'manageable'. The file indicates that there was rarely enough income coming into the household to cover anything more than basic needs, and often not even that. Mr. and Mrs. Peck and their children lived in overcrowded, insanitary and barely furnished sets of rooms. They often could not afford to meet their health or clothing needs. They were reliant on charities assessing their respectability and deciding whether or not they were poor enough to be helped, and for which help they were both shamed and grateful.

There are debates over whether or not, with the growth of the British post-war state system of comprehensive welfare support, the statutory role expanded at the expense of pre-existing forms of voluntary effort. For example, some argue that traditional forms of mutual-aid were a feature of vibrant civic life that was stifled. For others, the rise of state welfare in Britain was a response to the difficulties and deficiencies of the fragmented economy of welfare involving charitable and mutual-aid organisations, not least inequalities of assessment criteria, provision and distribution (Harris 2018). We have seen these inequalities of provision in the small history of the Pecks' lived experiences with COS, spanning nearly a quarter of a century. The granularity of the Peck case file records reveals how complex and bewildering the pre-war economy of welfare provision could be. The Pecks required the help of one charitable service, COS, to negotiate the labyrinth of state and charitable provisions. In the episodes from the Pecks' case file that we have referred to here, we see COS approaching and attempting to work across different state welfare departments and various specific charitable organisations to enable the Pecks to manage even the basics of life such as food and clothing.

Both the developing state provision and particularised charitable safety net had conditionality holes. There was the National Health Insurance scheme cut off that first propelled the Pecks to approach COS in 1928, and then later the Ministry of Health's judgement on Mr. Peck's fitness to work with no appeal. There was means-testing to assess whether or not grants were needed and could be repaid to ensure self-responsibility, the SSAFA judgement that the family's income was adequate, along with the National Temperance Hospital's initial estimation that the Pecks could afford to pay, and the to and fro between COS and Invalid Kitchens of London about Mr. Peck's ability to pay for his nourishing dinners. There was the Unemployment Assistance Board ruling out support because Mrs. Peck was a mother not a wife, and later her ineligibility for a means-tested supplementary pension to the basic state pension. Additionally, when nascent state provision failed, there was the need for the Pecks to be judged a respectable family, with the estimation of their hard-working character and neat appearance of their home from COS's first home visit, and the need to stress this and Mr. Peck's war record to the mainly armed forces charitable safety net that COS helped to put in place.

The small history of the Pecks' lived experience of poverty, precarity and negotiating the fragmented British economy of welfare of the interwar period provides us with a glimpse into a possible future of what Britain's current welfare settlement trajectory might mean for similar families yet to come. It is a nuanced rather than straightforward scenario. Will a form of Charitable Organisation Society, with its local knowledge of and ability to stitch together possible sources of help and support, be necessary for them, where a localised and far from comprehensive charitable sector has replaced the universal state? Additionally, with social entitlement so constrained and conditionality and sanctions common, will people-especially those not regarded as worthy, fall through the holes in that charitable safety net, leaving them destitute? Yet the Pecks' lived experience of the vagaries of British welfare provision over time also contains another, more muted story and possible insights. However unsatisfactory the fragmented economy of welfare of the interwar period with its myriad, localised and particularistic charitable sector safety net, the Pecks' small history also reveals that there were at least alternatives. If the state cut off or did not provide sufficient support for managing out- and in-work 
poverty and ill health, and if one charity ruled out help, then another in the localised welfare settlement might be approached to step into the breach. There is also the small, perhaps idiosyncratic lived experience for the Peck family that the advent of the post-war comprehensive British welfare state and retreat of charities into narrow tasks could break down what they experienced as a reliable frontline welfare support system. Their longstanding social and material source of advice and provision had crumbled, and the Pecks were left adrift in the midst of a comprehensive welfare state.

Author Contributions: Both authors contributed equally to all elements of the research analysis and writing up for this article. All authors have read and agreed to the published version of the manuscript.

Funding: This research was funded by the ESRC under its Secondary Data Analysis Initiative, grant number ES/G031029/1, and was conducted in partnership with Family Action.

Acknowledgments: In addition, Nicola Horsley worked on the wider project, and Annika Coughlan took the photographs.

Conflicts of Interest: The authors declare no conflict of interest.

\section{References}

Barnett, Richard. 2017. The Smile Stealers: The Fine and Foul Art of Dentistry. London: Thames \& Hudson.

Baumgartner, J. Craig, José F. Siqueira Jr., Christine M. Sedgley, and Anil Kishen. 2008. Microbiology of endodontic disease. In Ingle's Endodontics. Edited by John I. Ingle, Leif K. Bakland and J. Craig Baumgartner. Hamilton: BC Decker Inc, pp. 221-24.

Cole, Dorothy, and J. E. G. Utting. 1962. The economic circumstances of old people. In Occasional Paper in Social Administration 4. Welwyn: Caldicott Press.

Crossley, Stephen, Kayleigh Garthwaite, and Ruth Patrick. 2019. The Fragmentation of Poverty in the UK: What's the Problem? A Working Paper. Available online: https://static1.squarespace.com/static/ 5d3ef1aa7c54410001ea5ef3/t/5d9a73f33fc8223140de167b/1570403322350/UK+Poverty+-+what\%27s+the+ problem+Working+Paper+FINAL.pdf (accessed on 28 May 2019).

Ebbinghaus, Bernard. 2019. Pension reforms and old age inequalities in Europe: From old to new social risks. Paper presented at the 14th European Sociological Association Conference, Manchester, UK, August 20-23.

Ermiston, Daniel. 2017. Welfare, austerity and social citizenship in the UK. Social Policy and Society 16: 261-70. [CrossRef]

Farnsworth, Kevin, and Zoe Irving, eds. 2015. Social Policy in Times of Austerity: Global Economic Crisis and the Politics of Welfare. Bristol: Policy Press.

Finlayson, Geoffrey. 1994. Citizen, State and Social Welfare in Britain, 1830-1990. Oxford: Clarendon Press.

Garthwaite, Kayleigh. 2016. Hunger Pains: Life Inside Food Bank Britain. Bristol: Policy Press.

Gazeley, Ian. 2003. Poverty in Britain, 1900-1965. Basingstoke: Palgrave Macmillan.

Goulden, Chris. 2019. It's Wrong That So Many Working Families Are Trapped in Poverty-It's Time for Action. Joseph Rowntree Foundation Blog. Available online: https://www.jrf.org.uk/blog/its-wrong-somany-working-families-are-trapped-poverty (accessed on 29 May 2019).

Green, Alix R. 2016. History, Policy and Public Purpose: Historicans and Historical Thinking in Government. Basingstoke: Palgrave Macmillan.

Harris, Bernard. 2004. The Origins of the British Welfare State: Social Welfare in England and Wales, 1800-1945. Basingstoke: Palgrave Macmillan.

Harris, Bernard. 2018. Social policy by other means? Mutual aid and the origins of the modern welfare state in Britain during the nineteenth and twentieth centuries. Journal of Policy History 30: 202-35. [CrossRef]

Humphreys, Robert. 2001. Poor Relief and Charity, 1869-1945: The London Charity Organisation Society. Basingstoke: Palgrave Macmillan.

Jobs, Richard I., and Patrick McDevitt. 2005. Where the hell are the people? Journal of Social History 39: 309-14. [CrossRef]

Kasmir, Sharryn. 2018. Precarity. In The Cambridge Encyclopedia of Anthropology. Available online: https: //www.anthroencyclopedia.com/entry/precarity (accessed on 29 May 2019).

King, Steven, and Alannah Tomkins, eds. 2003. The Poor in England, 1700-1850: An Economy of Makeshifts. Manchester: Manchester University Press. 
Laite, Julia. 2020. The emmet's inch: Small history in a digital age. Journal of Social History. Available online: https://academic.oup.com/jsh/advance-article-abstract/doi/10.1093/jsh/shy118/5315914? redirectedFrom=fulltext (accessed on 28 May 2019). [CrossRef]

Lambie-Mumford, Hannah. 2019. The growth of food banks in Britain and what they mean for social policy. Critical Social Policy 39: 3-22. [CrossRef]

Lepore, Jill. 2001. Historians who love too much: Reflections on microhistory and biography. The Journal of American History 88: 129-44. [CrossRef]

Lewis, Jane. 1995. The Voluntary Sector, the State and Social Work in Britain: The Charity Organisation Society/Family Welfare Association Since 1869. Cheltenham: Edward Elgar.

Magnússon, Sigurður Gylfi. 2014. "The singularisation of history": Social history and microhistory within the postmodern state of knowledge. Journal of Social History 36: 701-12. [CrossRef]

McIntosh, Ian, and Sharon Wright. 2019. Exploring what the notion of 'lived experience' offers for social policy analysis. Journal of Social Policy 48: 449-67. [CrossRef]

Middlemass, Lucie, Ross Gillard, Victoria Pellicer, and Koen Straver. 2018. Plugging the gap between energy policy and lived experience of energy poverty: Five principles for a multidisciplinary approach. In Advancing Energy Policy: Lessons on the Integration of Social Sciences and Humanities. Available online: https://link.springer.com/content/pdf/10.1007\%2F978-3-319-99097-2.pdf (accessed on 28 May 2019).

Newstadt, Richard E., and Ernest R. May. 1986. Thinking in Time: The Uses of History for Decision-Makers. London: Free Press.

Noble, Virginia A. 2009. Inside the Welfare State: Foundations of Policy and Practice in Post-War Britain. Abingdon: Routledge.

Peel, Mark. 2011. Miss Cutler and the Case of the Resurrected Horse. Chicago: Chicago University Press.

Rooff, Madeline. 1972. A Hundred Years of Family Welfare: A Study of the Family Welfare Association (Formerly Charity Organisation Society) 1869-1969. London: Michael Joseph.

Runswick-Cole, Katherine, Rebecca Lawthorn, and Dan Goodley. 2016. The trouble with "hard working families". Community, Work and Family 19: 257-60. [CrossRef]

Shave, Samantha A. 2009. The dependent poor? (Re)constructing the lives of individuals "on the parish" in rural Dorset, 1800-1832. Rural History 20: 67-97. [CrossRef]

Shildrick, Tracy. 2018. Poverty Propaganda: Exploring the Myths. Bristol: Policy Press.

Starkey, Pat. 2007. Retelling the stories of clients of voluntary social work agencies in Britain after 1945. In Medicine, Charity and Mutual Aid: The Consumption of Health and Welfare in Britain C. 1550-1950. Edited by Anne Borsay and Peter Shapely. Aldershot: Ashgate, pp. 245-61.

Stevenson, John, and Chris Cook. 1979. The Slump: Society and Politics during the Depression. London: Quartet Books.

Taylor-Gooby, Peter, Benjamin Leruth, and Heejung Cheung. 2017. Where next for the UK welfare state? In After Austerity: Welfare State Transformation in Europe after the Great Recession. Edited by Peter Taylor-Gooby, Benjamin Leruth and Heejung Chung. Oxford: Oxford University Press, pp. 48-66.

Thane, Pat. 1982. The Foundations of the Welfare State. London: Longmans.

Thane, Pat. 1990. Government and society in England and Wales, 1750-1914. In The Cambridge Social History of Britain, 1750-1950, Vol. 3, Social Agencies and Institutions. Edited by F. M. L. Thompson. Cambridge: Cambridge University Press, pp. 1-62.

Thane, Pat. 2019. Divided Kingdom: A History of Britain, 1900 to Present. Cambridge: Cambridge University Press. Todd, Selina. 2007. Breadwinners and dependents: Working-class young people in England, 1981-1955. International Review of Social History 52: 57-87. [CrossRef]

Watts, Beth, and Suzanne Fitzpatrick. 2018. Welfare Conditionality. Abingdon: Routledge.

Zweiniger-Bargielowska, Ina. 2002. Austerity in Britain: Rationing, Controls and Consumption. Oxford: Oxford University Press.

(C) 2020 by the authors. Licensee MDPI, Basel, Switzerland. This article is an open access article distributed under the terms and conditions of the Creative Commons Attribution (CC BY) license (http://creativecommons.org/licenses/by/4.0/). 